\title{
STAGE MODELS OF \\ CORPORATE 'GREENING': A CRITICAL EVALUATION
}

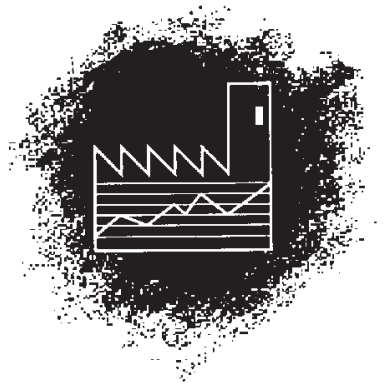

\author{
Anja Schaefer ${ }^{1 *}$ and Brian Harvey ${ }^{2}$ \\ ${ }^{1}$ King's College London, UK \\ ${ }^{2}$ Manchester Business School, UK
}

Corporate 'greening', i.e. the process by which companies can become more environmentally responsible in their operations, has attracted considerable interest lately. Largely born out of hands-on consultancy experience, various models have been proposed which describe a series of 'stages' by which companies become progressively more environmentally conscious and reduce their impact on the natural environment. The present article critically analyses some of these 'stage' models of corporate 'greening' from both an empirical and a management theoretical point of view. The empirical analysis is based on four case studies of the 'greening' efforts of companies in the UK water and electricity industries. Environmental strategy and management in these companies is found to fit poorly into

${ }^{*}$ Correspondence to: Dr Anja Schaefer, The Management Centre, King's College, London, Kensington Campus, Campden Hill Road, London W8 7AH.

Contract grant sponsor: Economic and Social Research Council. Contract grant number: L 321253209.

CCC 0964-4733/98/030109-15 \$17.50

(C) 1998 John Wiley \& Sons, Ltd and ERP Environment. the stage models of corporate 'greening'. The article concludes that more comprehensive and interpretative explanations of organizational 'greening' are needed, including contextual and process oriented analysis. (C) 1998 John Wiley \& Sons, Ltd and ERP Environment.

Received 7 November 1997

Revised 3 March 1998

Accepted 7 April 1998

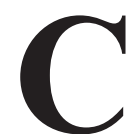
orporate 'greening', the process by which companies can become more environmentally responsible in their activities, has attracted considerable interest over the last decade. Much has been written about the need for industry to take a lead in creating a more environmentally sustainable society (see e.g. Schmidheiny, 1992; Stead and Stead, 1996). Consequently, a host of tools to aid environmental management have been developed, such as environmental management systems, life-cycle assessment, environmental reviews and audits, etc. (see e.g. Garrod and Chadwick, 1996) and there is no shortage of academics and consultants offering their advice for managing environmental issues (Shrivastava, 1995; Wally and Whitehead, 1994; Elkington, 1994; Newman, 1993; 
Winsemius and Guntram, 1992; Roome, 1992; Greeno, 1991; Kleiner, 1991; Hunt and Auster, 1990; and many more). Yet, despite numerous publications on the theme, theoretical development is still in its infancy. The models suggested so far are largely prescriptive and based on consultancy experience. The majority describe a series of 'stages' by which companies become progressively more environmentally conscious and reduce their impact on the natural environment (Newman, 1993; Winsemius and Guntram, 1992; Roome, 1992; Greeno, 1991; Hunt and Auster, 1990).

The underlying assumptions of all these models appear to be that (i) companies have a choice of environmental strategy or position and (ii) there is a line of progression from a company that is not engaged, not interested in environmental issues through to the other extreme where a company is highly interested, takes active responsibility for environmental issues and becomes an environmental leader. Companies are assumed to move, or at least be able to move, in stages along this line.

The models vary in the number and definition of stages. Newman (1993) suggests three stages: 'reactive', 'pro-active' and 'innovative'. The individual stages are not well defined but they broadly represent a company's attitude to environmental risk and opportunity. 'Reactive' companies are supposed to see environmental issues in terms of risk whereas innovative' companies link them with significant opportunities.

Winsemius and Guntram (1992) conceive of four stages in corporate environmental response: 'reactive', 'receptive', 'constructive' and 'proactive'. They define them in terms of integration of business functions, co-operation of people and organizations and generation of new ideas and concepts.

Roome's (1992) model of corporate strategic response to environmental issues is one of the more comprehensively defined. He distinguishes between five strategic options ('non-compliance', 'compliance', 'complianceplus', 'commercial and environmental excellence' and 'leading edge'). The first four are conceived as stages on a developmental continuum whereas the fifth option defines the environmental leaders for a given industry, regardless of their position on the 'non-compliance' to 'excellence' continuum.

Greeno (1991) describes three stages defined in terms of primary purpose, primary motivations and vulnerability of environmental management. The best defined of the stage models discussed here is probably that by Hunt and Auster (1990). Like Roome (1992) they conceive of five stages on the route to environmental excellence: 'beginner', 'fire fighter', 'concerned citizen', 'pragmatist' and 'pro-activist'. They define these stages in terms of risk reduction, commitment and programme design, with a number of sub-criteria. The models by Roome (1992) and by Hunt and Auster (1990) are described in more detail in the appendix.

\section{METHODOLOGY}

In this paper we report and discuss the results of an empirical study designed to test the stage models developed by Hunt and Auster (1990) and by Roome (1992). The study was carried out with four companies in the UK water and sewerage and electricity distribution sectors during 1996 and 1997. These industries were chosen because of the 'test bed' situation provided by the privatization of the public water and electricity authorities in 1989. Prior to that, organizations in each sector were considered to be fairly homogenous - a hypothesis generally supported by the managers we spoke to. Privatization gave them a chance to develop different strategic directions, which may include their handling of environmental issues. Thus, any stages or strategic choices with respect to environmental management should be relatively easily observable and less confounded by different historical development than in many other industries.

While these industries may perhaps not conform to the typical image of highly polluting industries, such as chemicals or pulp and paper, they have nonetheless significant environmental impacts. These are more direct in the case of the water industry, which has been heavily criticized for a variety of negative environmental impacts, such as pollution of rivers and coastal waters by sewage effluent, the dumping of raw sewage at sea and, more recently, over-abstraction of fresh water from rivers and aquifers. The electricity distribution companies, also known as regional electricity companies (RECs), have fewer, although not insignificant direct environmental impacts, mostly through oil and chemical pollution from underground cable networks and sub-stations. However, their most significant 
environmental impact may well lie in the product they sell, i.e. electricity and the associated problems of pollution at generation, depletion of natural resources, $\mathrm{CO}_{2}$ emissions and similar issues. Resulting from the perceived difference in the severity of their direct environmental impacts, the two sectors are subject to different levels of specific environmental legislation. In the case of the water industry this is very significant, much of it emanating from the European Union, and the British water industry has been criticized in the past for not meeting European environmental standards. The electricity distribution industry is subject mostly to general environmental legislation, applying to all industry sectors. These differences between the industries allow some interesting comparisons to be made.

Data for this paper was gathered within a larger study, involving six water and sewerage and RECs. A test of the stage models is not the primary purpose of this larger study but sufficient data was gathered to make an attempt to classify four of the companies according to the stages. All companies in the sample granted us ready access to their managers and printed materials but asked not to be named in resulting publications. They are therefore referred to as companies A, B, C and $\mathrm{D}$ in the remainder of the paper. As the main purpose of the paper is not to set shining examples nor to 'name and shame' supposed wrong-doers but rather to offer some insight into the applicability of a popular conceptual framework to the environmental strategy and management of a number of companies in two different industry sectors, we believe that granting such anonymity to participating companies will not hamper the interpretation of the findings.

Companies $\mathrm{A}$ and $\mathrm{D}$ are RECs, company $\mathrm{B}$ is a water and sewerage company and company $C$ is a multi-utility. All companies are former public authorities, privatized in 1989 and now fully in private ownership. One had been taken over and two more were in the process of being taken over by foreign companies at the time of our research but this had not yet produced any significant impact on their environmental strategy and management. All companies in our sample - as indeed both industries in general - have been making healthy profits since privatization.

Data was gathered through qualitative interviews with a variety of managers at different levels in the corporate hierarchy. In all companies we interviewed a small number of top and senior managers at group level, the full-time environmental manager and between six and 12 further managers at divisional level, all of whom had environmental responsibilities but mostly not as a full-time brief. These managers came from different functions within the companies, the majority but not all of them from divisions or functions with significant environmental impacts. Interviews lasted between one and two hours and were conducted according to a semi-structured schedule, designed to elicit information on a number of specific topics but also to give respondents the freedom to talk about issues that they considered important. Interviews were tape recorded wherever possible and full transcriptions made. In about 10\% of cases tape recording was not possible, either because respondents were not comfortable with the idea or because of high levels of background noise. In these cases extensive notes were taken during and immediately after the interview. Interviews were analysed by coding responses and searching for emergent themes, as well as a specific search for predetermined types of data (such as the existence and certification of environmental management systems, environmental policy and targets, staffing and activities of the environmental function).

\section{RESULTS}

Hunt and Auster give a table of criteria across all five of their stages (Hunt and Auster, 1990, p 9). Hass (1996) tried to use these criteria to classify eight Norwegian companies and found that only six of the 12 criteria were usable in the Norwegian context. In a British context more of the criteria suggested by Hunt and Auster seem usable. However, 'resource commitment' turned out to be highly difficult, if not impossible to operationalize as 'open ended funding' does not seem a reasonable expectation and 'sufficient funding' seems too vague because what is sufficient depends on the intended purpose. Furthermore, 'product design' is not a readily meaningful concept in the context of water and electricity utilities, and this criterion was therefore also left out.

Table I summarizes our attempt to classify the case study companies according to the criteria offered by Hunt and Auster (1990, p 9). 
Table 1. Classification of companies according to criteria specified by Hunt and Auster (1990)

\begin{tabular}{|c|c|c|c|c|c|c|c|c|c|c|c|}
\hline & $\begin{array}{l}\text { Env. risk } \\
\text { reduction }\end{array}$ & $\begin{array}{l}\text { Mindset of } \\
\text { managers }\end{array}$ & $\begin{array}{l}\text { Top man. } \\
\text { support \& } \\
\text { involvement }\end{array}$ & $\begin{array}{l}\text { Performance } \\
\text { objectives }\end{array}$ & $\begin{array}{l}\text { Integration } \\
\text { with } \\
\text { company }\end{array}$ & $\begin{array}{l}\text { Reporting } \\
\text { to top } \\
\text { management }\end{array}$ & $\begin{array}{l}\text { Reporting } \\
\text { structure }\end{array}$ & $\begin{array}{l}\text { Involvement } \\
\text { with legal } \\
\text { counsel }\end{array}$ & $\begin{array}{l}\text { Involvement } \\
\text { with PR }\end{array}$ & $\begin{array}{l}\text { Involvement } \\
\text { with } \\
\text { operation }\end{array}$ & Average \\
\hline Comp. A & $3^{*}$ & $\frac{3}{4}$ & 4.00 & 4.00 & 3.00 & $4 / 5$ & 5.00 & $1 / 2$ & $2 / 3$ & 4.00 & 3.50 \\
\hline Comp. B & $4 / 5$ & 4.00 & 4.00 & $4 / 5$ & $4 / 5$ & 5.00 & 5.00 & $3 / 4$ & $2 / 3$ & $4 / 5$ & 4.20 \\
\hline Comp. C & $2 / 3$ & 4.00 & $4 / 5$ & 3.00 & $\frac{3}{4}$ & $4 / 5$ & 4.00 & $1 / 2$ & $2 / 3$ & $3 / 4$ & 3.50 \\
\hline Comp. D & $3 / 4$ & 4.00 & 4.00 & 4.00 & $4 / 5$ & 5.00 & 5.00 & 4.00 & $2 / 3$ & $4 / 5$ & 4.10 \\
\hline
\end{tabular}

*These figures denote the stages in Hunt and Auster's (1990, p. 9) model, where $1=$ 'Beginner', $2={ }^{\prime}$ Fire fighter', $3={ }^{\prime}$ Concerned Citizen', $4={ }^{\prime}$ Pragmatist' and $5={ }^{\prime}$ Pro-activist'. See Hunt and Auster 1990, p. 9 for a specification of the stages in their model.

It proved difficult to classify companies unequivocally according to individual criteria. Very often it was only possible to say that a company seemed to fall into either of two possible stages. For instance, we found it difficult to determine whether the environmental risk reduction offered by a company's environmental programme was 'minimal' (stage 2), 'moderate' (stage 3), 'comprehensive' (stage 4) or 'maximum' (stage 5). Similar problems existed with a number of other criteria. Even leaving aside this difficulty the classification of individual companies was far from consistent across the criteria. For instance we deemed that company A had a reporting structure associated with stage 5 but the involvement of its environmental programme with its legal department was more or less non-existent, i.e. consistent with stage 1 or 2 . Similar inconsistencies occur with all four companies across a number of criteria. This supports findings by Hass (1996).

In the text of their paper Hunt and Auster (1990) also offer a number of further descriptors for their five stages. These are not always specified across all five stages in a consistent fashion. While some of these additional descriptors are mutually exclusive between the stages, others have to be seen as cumulative, in the sense that a company at, say, stage 3 is expected to show certain characteristics, with further characteristics being added at stages 4 and 5 without losing the characteristics already acquired at stage 3. Classifying companies according to these additional criteria might therefore prove even more difficult than according to those presented in Table 1 . Even so, we felt that it would be useful to make an attempt.

Table 2 summarizes these additional descriptors of the Hunt and Auster model. We have grouped them into seven categories, where each category can have more than one descriptor. If we felt that a company in our sample exhibited the described characteristic we put its letter (A, B, C or $\mathrm{D})$ after the descriptor in question. Where we were not entirely sure whether the company showed a particular characteristic, or where such a characteristic was only partly shown, the identifying letter of the company is put in brackets.

As some of the descriptors presented in Table 2 are mutually exclusive between stages and others appear to be cumulative the results are not altogether easy to interpret. Some of the mutually exclusive descriptors show inconsistencies in the classification. While all four companies can be said to have environmental departments with sufficient expertise, funding and authority (stage 4) and one can be said to have a very visible, high profile environmental director (stage 5) all these departments are nonetheless very small (stage 2). It is therefore difficult to determine where on the scale the companies should be placed. Likewise, all the companies exhibit some characteristics consistent with stage 5 but none of them exhibits all these characteristics. The model does not, unfortunately, specify whether only a company showing all characteristics associated with stage 5 can be considered to have reached this stage. However, we can differentiate between the four companies based on the number of stage 5 characteristics that they show (company A, eight; company B, 16; company C, seven; company $\mathrm{C}, 12)$. This seems a clearer discriminator between the companies than their scores in Table $I$ but whether it is consistent with the intentions of Hunt and Auster is not clear.

Roome (1992) does not specify consistent criteria across all his five strategic options. In fact, as only the first four of these options 
represent stages along a continuum we shall leave aside option 5 ('Leading Edge'). In attempting some operationalization of his model we have chosen the same method as with the additional descriptors of the Hunt and Auster (1990) model. In Table 3 we have grouped the descriptors given by Roome (1992) into eight categories. Again, each category may contain more than one descriptor. As in Table 2 we have placed a company's identifying letter after any descriptor if we felt the company showed this characteristic.

As with the additional descriptors in the paper of Hunt and Auster, Roome's descriptors are a mixture of mutually exclusive and cumulative ones. The descriptors of stage 1 all seem to be mutually exclusive with those of any other stage. However, the characteristics of the higher stages seem largely cumulative. Some of these characteristics proved very difficult to determine, let alone measure. Two of these were 'systems thinking' and 'respect for people' (stage 5), both of which we felt unable to determine with any semblance of reliability. In interpreting the results we encounter the same problems as with the results presented in Table 2 . It is impossible to determine the current stage of 'greening' of any company reliably. Firstly, we found it often quite difficult to determine whether a company showed a certain characteristic or not. If we felt a characteristic was shown in part but not fully we placed the respective company identification letter in brackets. The large number of letters in brackets in Table 3 reflects the difficulties we had in classifying companies.

Secondly, none of the four companies displays a profile of characteristics that would place it unequivocally at any particular stage. For instance, all four companies can be said to at least strive for a 'pro-active attitude towards environmental issues' and all 'look beyond current legal requirements' but there is only limited 'change to organizational structures and systems' in any of the companies, all of which are supposed to be characteristics of stage 3. None of the companies carries out systematic green stakeholder analysis (a requirement of stage 2) although all four have regular contacts with some stakeholders. So it seems the companies have reached stage 3 in some aspects but have not even fully reached stage 2 in other aspects. Roome (1992), like Hunt and Auster (1990), does not make it clear whether this is a legitimate interpretation of his model or whether a company is expected to fulfil all criteria of a given stage at the same time.

\section{DISCUSSION OF THE FINDINGS}

In the previous section we tried to classify four companies according to the stage models of corporate 'greening' proposed by Hunt and Auster (1990) and Roome (1992). The problems encountered in this attempt fall into two areas: (i) difficulties in operationalizing the criteria of individual stages in a way that would allow rigorous empirical testing of the models and a consequent difficulty in assessing whether a company fulfilled a given criterion or not and (ii) the inconsistent showing of companies across different criteria resulting in problems in interpreting the results of companies' scores according to the models.

Problems in operationalizing the criteria for individual stages seem to arise mainly because the stage models are conceptual models, not necessarily intended to be tested empirically. Consequently many of the criteria are vague and not consistently defined across stages. In many cases it seems impossible to define the criteria more tightly as their precise meaning will often depend on the specific industry, company and even site one is looking at. For instance, what constitutes 'comprehensive environmental risk reduction' (Hunt and Auster, 1990) must surely differ between, say, a chemical company and a tele sales operation. It would also seem to differ between the two industries considered in this study, for instance when looking at issues such as oil pollutionmore important for the electricity distribution companies - or waste disposal - more important in the water and sewerage companies with large quantities of sewage sludge and spoil from roadwork to dispose of. Similarly, whether the involvement of a legal advisor in a company's environmental programme is necessary or not probably depends on the size of the company and the significance of its environmental effects.

As a consequence of the difficulty in operationalizing criteria for individual stages it often proved difficult to determine whether a company showed a certain characteristic specified by the models or not. Very often we were only able to say that a company probably fell into either of two adjacent stages and even that with only a moderate degree of certainty. This makes the empirical test conducted quite unreliable even though two researchers were involved in the exercise. This weakness would seem to be inherent in the models tested and may be difficult if not 
Table 2. Additional criteria for stages of Hunt and Auster (1990)

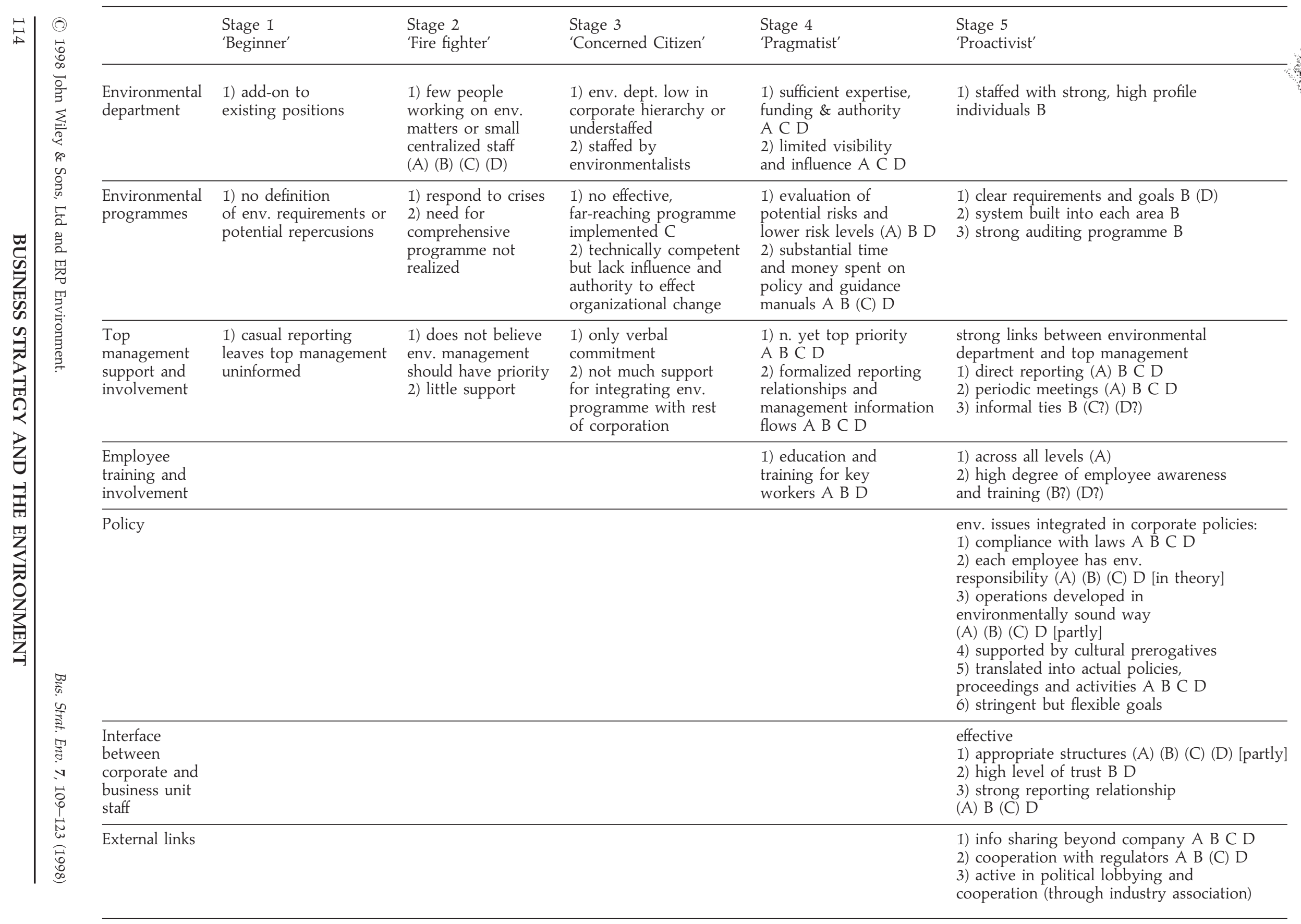


Table 3. Criteria for stages of Roome (1992)

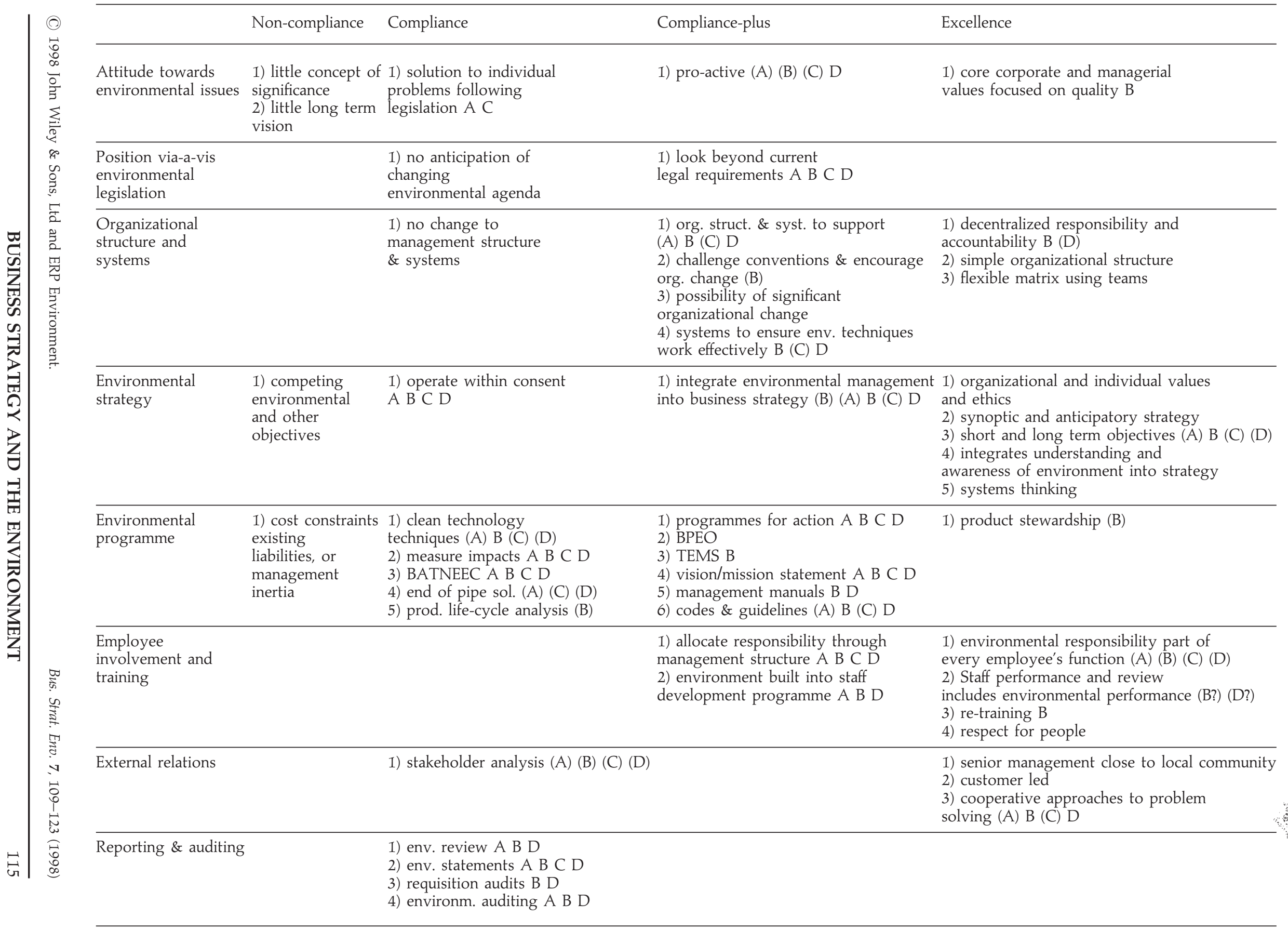

ding and

5) systems thinking
1) programmes for action $A B C D$
4) vision/mission statement $A B C D$

1) allocate responsibility throug

involvement and

ent structure A B C D

) senior management close to local community

solving (A) B (C) D

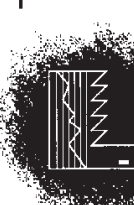


impossible to overcome, regardless of the precise methodology used.

The second problem encountered was that companies seemed to fit into different stages depending on which criteria were used. While the above mentioned difficulties in accurately determining a company's stage according to a single criterion may explain some of these inconsistencies they cannot, in our opinion, account for all the inconsistencies found. Some of the gaps are simply too wide to be caused by inaccurate rating, for instance where company A has 'formalised internal and external reporting mechanisms' (stage 5 according to Hunt and Auster, 1990, p 9) but practically no involvement of the legal department in environmental matters (stage 1 , Hunt and Auster, 1990, p 9).

These findings prompt the question why a classification of companies according to these widely respected models turns out to be so difficult. One possibility could be that the models are simply insufficiently specified in their current form, and that, with the help of further empirical research, it might be possible to define a number of mutually exclusive, unambiguous and clearly specified developmental stages of environmental strategy, so as to allow a clearer classification of companies. Yet, the understanding gained from our study leads us to believe that there are deeper problems involved, which may make such an attempt to define stages in a clear and unambiguous way impossible.

It seems to us that at least some of the problems discussed stem from the fact that these models imply a linear, one-dimensional progression on all fronts, whereas in reality the process may be much more multi-faceted. There seems to be no logical reason why a company cannot embark on far-reaching internal and external reporting without at the same time integrating the entire company in the environmental management process. Likewise, the fact that an environmental department is small does not necessarily imply that it cannot be headed by a high profile, influential manager. According to our findings, which environmental issues a company tackles first, where the impetus for environmental management comes from, what form of reporting is chosen, the extent of employee involvement, the emphasis that is placed on legal compliance, etc. seems to depend to a considerable extent on the industry in question and on the specific circumstances of the company. While Hunt and Auster acknowledge that different companies may need different approaches to environmental manage- ment, the specification of their model does not take such differences into account. The same applies to Roome's (1992) model. If 'corporate greening' is indeed a multi-dimensional process, which is also dependent on a multitude of industry and company specific contingencies, then an inconsistent showing across any onedimensional model is perhaps not particularly surprising.

\section{Some Conceptual Limitations of the Models}

If an insufficient specification is not the main or only reason for the difficulties in classifying individual companies according to the stage models tested we should turn our attention to the bases and underlying assumptions of these models.

Much of what has been written about corporate 'greening', not just the five stage models described in the first section of this article, tends to be highly prescriptive. The reason for this may lie in the intended purpose, which is to motivate and persuade managers to take environmental issues seriously and guide them in reducing the environmental impact of their businesses, but this may not coincide with the way in which the 'greening' process occurs in practice and it is not clear whether the authors are realistic in their expectations that business will reach the final stages in their models and take on environmental leadership.

Another root of the problem may lie in the models' underlying conceptualization of organizational and strategic change, which is largely based on a classical notion of strategic choice and top-down planning (Ansoff, 1965; 1979; Chandler, 1962; 1977). Roome (1992) spells this out clearly but the other models work on a similar assumption. While the classical approach to strategy remains popular in both academia and management practice it has nonetheless met with substantial criticism. By and large, the strategic planning school assumes that managers - as well as other economic actors - act according to a fairly narrow economic rationale (homo economicus), have - or are able to obtain near perfect information about both their own organizations and the business environment, and have wide reaching discretion to implement any chosen strategy within their organizations (Whittington, 1993). In reality, however, managers often act out of personal, emotional, political and affective reasons, just like everybody else. Neither is it possible for them to gather all relevant information about the business 
environment, and, even if they could do so, time restrictions would make it impossible for them to attend to all that information (Pettigrew and Whipp, 1991). Furthermore, some types of information lend themselves more easily to quantification than others and an over-reliance on 'hard', factual data prejudices decision makers in favour of such quantifiable information, at the cost of 'softer' but often equally if not more important other information (Mintzberg, 1994). Finally, organizations are not the biddable tools that some writers would have us believe, but often act according to their own inner logic and culture, which management may find difficult, if not impossible to change at will (Morgan, 1997). Mintzberg (1994) criticizes the entire notion of strategy that is being formulated at the top and then implemented throughout the organization and advances the notion of emergent strategy, which is developed in various parts of the organization and builds up to an overall strategy in an incremental fashion. With this in mind, Räsänen et al. (1995) argue for a more interpretative view of corporate 'greening' which does at least contemplate the possibility of a bottom-up process.

Some theorists even question the very possibility of orderly, planned change at organizational level. Gersick (1991) and Tushman and Romanelli (1985) suggest that organizational change is more likely to be discontinuous and revolutionary, following a major crisis (the punctuated equilibrium), whereas population ecologists like Freeman and Hannan (1993) contend that individual organizations are highly unlikely to adapt successfully to changing circumstances and that change will mostly occur at population level through the emergence of new, more successful organizations. Yet, even if we accept the notion of ordered change at organizational level it is by no means clear that this change has to be linear and progressive. It seems perfectly possible that companies reach a certain level of 'greenness' and then fail to move any further, or even regress to less environmentally responsible modes of operation.

By focusing on the classical, planning approach to organizational change the stage models in effect reduce all the changes involved in 'greening' to a single dimension (Hass, 1996). Yet, organizational change is often thought to involve several dimensions which may not be reducible to one common denominator. Pettigrew (1988) describes strategic change within the three dimensions of content, external and internal context and process, which interlink and influence each other. According to Pettigrew, strategic change emerges out of the dynamics produced by this link and mutual influence between all three dimensions and he suggests that one of the problems of much strategic research lies in a failure to consider properly the dimensions of process and internal context in particular. A similar point is made by Wilson (1992), who criticizes skill-based approaches to managing organizational change, ready-made models of best practice and an overreliance on the notion of change as the outcomeoriented pursuit of great and charismatic leaders. Instead, he advocates stronger emphasis on the potency of organizational structure, of the determining impact of factors at a larger socioeconomic level, and the institutionalizations within which managers must operate. He suggests that strategic and organizational change should be analysed at multiple levels, involving individuals, organizations and wider social and economic contexts.

All this is not to suggest that environmental strategy and management will not often develop over time or that there are no significant differences between companies in this respect. For instance, company B embarked on the corporate 'greening' process relatively soon after privatization, in the early 1990s. It has a certified environmental management system for its core business and actively pursues innovative environmental options in the development of new assets. Currently the company seeks to integrate the environmental management activities of its individual business more fully at group level. Yet, managers in the company feel that environmental awareness and employee involvement need improvement and that the company is less advanced in the management of wider environmental impacts than in managing regulatory environmental issues.

By comparison, company C only started a systematic environmental management process in 1995. This followed considerable re-structuring during which emerging environmental management structures of individual constituent businesses were partly abandoned and partly integrated in the new, group wide approach. Contrasting with company B, and also company $D$, where environmental management systems were first developed in certain core business areas and a group wide structure is being built up as a subsequent step, company $\mathrm{C}$ is immediately aiming for a coherent environmental management system for the entire group. Yet, environmental 
awareness and expertise exist to rather different degrees in different constituent businesses and appropriate structures are still at an early stage of development in many areas. Managers in all four companies clearly see environmental management as a learning process, suggesting that it takes several years for a company to develop appropriate measurements of effects, set sensible, quantifiable targets to reduce such effects and put measures in place that will achieve these targets. Raising overall environmental awareness throughout a company and developing environmental expertise in individual members and across the organization equally takes time.

\section{Broadening the Theoretical Framework}

If the stage models discussed here are insufficient as a theoretical basis for the study of organizational 'greening', alternative concepts and models have to be sought. One possibility might be a classification where a large number of desirable characteristics of an environmentally responsible company are gathered through qualitative interviews with experts, quantitative rating and cluster analysis and companies are then rated by the extent to which these criteria are present, but without grouping such criteria into stages or assuming that they be achieved in any particular order. In fact, our analysis of companies according to the additional criteria provided by Hunt and Auster (1990), discussed under 'Discussion of the findings' above, almost inadvertently came up with such a measure, whereby company A fulfilled eight of Hunt and Auster's additional criteria, company B fulfilled 16 , company $\mathrm{C}$ seven and company D 12 . This would seem to lead to some sort of league table, in the order of company B, company D, company $\mathrm{A}$ and company $\mathrm{C}$.

However, there are a number of potential problems with such an undertaking. (i) Will all the criteria provided, for instance, by Hunt and Auster (1990) or by any other potential list of factors be of equal importance or should they be weighted in any form? (ii) If environmental strategy and management is indeed a multi-level, multi-dimensional construct, is it at all conceivable that organizations could be ranked according to a single, compound score or would several scores be needed? If so, how would one reconcile potentially conflicting results? (iii) Perhaps most importantly, given that the ultimate aim of environmental management must be the reduction of environmental impacts, can we relate actual environmental performance to environmental strategy and management techniques in any meaningful and reliable way? In this respect comparing environmental impact across industries is likely to be a particularly difficult and possibly insurmountable problem.

Even with a more systematic approach to determining criteria and without prior assumptions concerning progress and stages, the theoretical limitations discussed in the previous section of the article still apply.

Rather, future research should work from a broader theoretical perspective than a narrow, classical definition of strategy. Whittington (1993) identifies three further perspectives on strategy:

'evolutionary' or institutional, which assumes that managers have limited capacity to assess their business environment and then choose an appropriate strategy to adapt to that environment in the rational, planned fashion proposed by the classical school but that the market will weed out inefficient firms (see e.g. Powell and DiMaggio, 1990; North, 1990);

'processual', which also stresses the bounded rationality and limited information-gathering capacity of firms but assumes that the market is generally quite forgiving of mistakes and suggests that company strategy is largely made by small, incremental steps emerging from past practice (see e.g. Mintzberg, 1994; Pettigrew and Whipp, 1991; Morgan, 1989; 1997) and 'systemic', which suggests that the way in which strategy is made and implemented is largely culturally constructed and that managers show the strategic behaviour which is expected of them.

Particularly the processual and the evolutionary perspectives, in addition rather than in opposition to each other and the classical approach, have something to offer research into environmental strategy and management. The evolutionary approach alerts us to the importance of external pressures both for and against stronger environmental management. We do not quite follow the deterministic aspects of this strand of theory, which would suggest an eventual convergence of all existing companies to one broad strategy, and would certainly doubt the market's ability to choose environmentally responsible over environmentally irresponsible businesses. Yet, the importance of external pressures on businesses in the area of environmental management cannot be 
denied. In our study we found that companies felt themselves subject to strong institutional pressures to become more environmentally responsible, such as national and European legislation, the pressures of the environmental regulator (the Environment Agency) and public pressure, expressed in opinion polls and related through the media. On the other hand, there were also significant institutional pressures against more far-reaching environmental management, for instance the insistence of economic regulators to keep prices down, which restrict capital investment into, say, new sewage treatment works or an early substitution of oil-filled underground electricity cables. The need to satisfy shareholders and make a profit also tended to work as a limiting factor to expenditure on environmental issues.

We also found organizational 'greening' to be strongly influenced by intra-organizational factors, such as the organization's capacity to learn, general operational control, organizational structure and the amount of spare management capacity. These impact not only on the success or otherwise - in implementing a chosen strategy but also on the strategies and tactics that emerge in the first place. This manifests itself in incrementalism, building on existing strengths and previous initiatives. Such internal factors can explain a large proportion of the differences we found in the details of environmental management in the companies studied. Companies with the greatest learning capacity and that are most aware of the emergent, processual aspects of environmental strategy may have greater success in adapting to the external pressures for greater environmental sensitivity.

Organizational learning theory may prove a useful angle to understanding some of the internal factors that seem to shape environmental management and strategy. In our research, the learning aspect to environmental matters was continuously stressed by managers. They emphasized how difficult it was to keep track of environmental information, including scientific and legislatory advances. Future research should look at the way in which organizations acquire environmental knowledge, how it is distributed through the organization, how it is interpreted by organizational actors and how it passes into organizational memory (see Huber, 1991). Hedlund's (1994) and Nonaka's (1994) observations on the transformation of tacit into explicit knowledge, Nonaka's (1994) thoughts on 'redundancy of information' and 'middle-up-down' manage- ment, and the suggestions of Nicolini and Meznar (1995) that, in order to effect real learning, the organization must move forward to what Morgan (1989) calls a loosely coupled organic network may help us in studying how companies can improve their environmental learning and move towards more environmentally responsible practices.

\section{CONCLUSION}

In this article we have tested two popular stage models of organizational 'greening' empirically and found that they had a not very good fit with the reality as we observed it in four case study companies. We believe that the reasons for this lie only partly in an insufficient specification of the models and would not necessarily be eliminated if criteria and stages were determined in a more systematic, empirical way. Rather, the underlying problems may lie in a limited vision of strategy and organizational change which does not give sufficient attention to multiple dimensions of change. We recommend that future research use broader, multi-dimensional theoretical frameworks, incorporating more detailed study of the institutional pressures and internal conditions and processes which shape individual companies' environmental strategy.

A final question arises from these findings and considerations. Do our criticisms of the stage models of corporate 'greening' matter, given that these models were probably never intended to serve as a means to classify and compare different companies accurately? The stage models offer a general guide to the direction a company should take if it wants to improve its environmental performance. They were not meant, perhaps, to be testable in the way attempted here. If they fulfil their purpose of motivating managers to improve the environmental performance of their company and give an indication how this might be achieved, can they not be accepted as a useful heuristic, bearing in mind that they are just that? Yet, their authors must still have assumed that their underlying assumptions and the course of actions and events they outline are a reasonably accurate representation of reality. Furthermore, it seems that these models have come to be regarded as more than just a heuristic for practical purposes and are referred to as if this were in fact the way in which environmental strategy and management generally developed in companies 
that took the issues seriously. If this is not the case, at least not in all or perhaps even the majority of firms, then the unquestioning adoption of such heuristic models may easily lead to inappropriate recommendations and managerial actions. Certainly accumulation of knowledge through research is only likely to occur if comprehensive and appropriate theoretical frameworks are employed.

Therefore, more comprehensive, in-depth accounts of organizational 'greening', including the problems that this process may encounter, are needed to improve our understanding of organizational 'greening' beyond initially attractive but ultimately limited heuristics, such as the stage models. Such better understanding is likely to lead eventually to more useful recommendations for managers wanting to improve the environmental performance of their organizations.

\section{APPENDIX 1 - BRIEF SUMMARY OF THE MODELS BY HUNT AND AUSTER (1990) AND ROOME (1992)}

\section{Hunt and Auster (1990)}

The authors propose that there are five distinct stages of corporate environmental programme development along a continuum extending from 'beginner', which provides only minimal protection from environmental problems, to the 'proactivist', which is the most aggressive in reducing risk. They define these stages across 12 dimensions (see Table AI).

The authors also identify 'seven keys to protecting a company from environmental risk. These are

top level support and commitment (Hunt and Auster, 1990, p 12),

corporate policies that integrate environmental issues ( $\mathrm{p}$ 12),

effective interfaces between corporate and business unit staff (p 14),

a high degree of employee awareness and training (p 14),

a strong legal base (p 15) and

established ownership of environmental problems ( $p$ 15).

They further suggest six steps to successful implementation of an environmental protection programme: assessing the full range of environ-

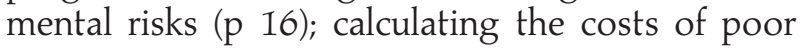

environmental management and selling the need for good practices throughout the corporation ( $p$ 16); finding a good environmental manager (p 16); organizing for visibility, accessibility and effectiveness ( $p$ 17); managing and using information flow (p 17) and re-evaluating and reforming existing programmes ( $p$ 17).

\section{Roome (1992)}

The author clearly bases his models on a classical model of strategic management, consisting of 'information and anticipation', 'formulation of strategy', 'implementation of programme' and 'measuring of outcomes'. He then develops a matrix of corporate vulnerability to environmental pressure, based on the two dimensions of 'scientific significance of environmental impact' and 'public perception of environmental impact'. This matrix is shown in Figure AI.

Roome suggests that this analysis leads to a rather pessimistic conclusion, i.e. that most companies are reactive to various shades of environmental threat. He proposes that most companies also 'need to track potential environmental vulnerabilities [and that this] even applies to companies which currently do not think they have environmental impacts or concerns' (p 18).

He then goes on to propose a model of five strategic options available to companies in shaping their strategic response to external environmental pressures. These are the following.

- Non-compliance. This is the option taken by companies that do not react to environmental pressure due to cost constraints, lack of long term vision or similar.

- Compliance. Solutions to individual environmental problems are developed as legislation sets the agenda.

- Compliance-Plus. A proactive position; integration of environmental management systems into the framework of business strategy; the company goes beyond the requirements of the law.

- Commercial and environmental excellence. The company takes to a logical conclusion the notion that good environmental management is good management.

- Leading edge. This description characterizes a company that is at the leading edge in its sector, using state of the art environmental management techniques. This is independent of 
Table A1. Developmental stages at corporate environmental management programme according to Hunt and Austêr (1990)

\begin{tabular}{|c|c|c|c|c|c|}
\hline & Stage 1 & Stage 2 & Stage 3 & Stage 4 & Stage 5 \\
\hline $\begin{array}{l}\text { Degree of } \\
\text { environmental } \\
\text { risk reduction }\end{array}$ & $\begin{array}{l}\text { No } \\
\text { protection }\end{array}$ & $\begin{array}{l}\text { Minimal } \\
\text { protection }\end{array}$ & $\begin{array}{l}\text { Moderate } \\
\text { protection }\end{array}$ & $\begin{array}{l}\text { Comprehensive } \\
\text { protection }\end{array}$ & $\begin{array}{l}\text { Maximum } \\
\text { protection }\end{array}$ \\
\hline \multicolumn{6}{|l|}{ Commitment } \\
\hline $\begin{array}{l}\text { Mindset of } \\
\text { managers }\end{array}$ & $\begin{array}{l}\text { Environm. } \\
\text { management } \\
\text { unnecessary }\end{array}$ & $\begin{array}{l}\text { Environm. } \\
\text { issues only } \\
\text { to be addressed } \\
\text { as necessary }\end{array}$ & $\begin{array}{l}\text { Environm. } \\
\text { management } \\
\text { worthwhile } \\
\text { function }\end{array}$ & $\begin{array}{l}\text { Environm. } \\
\text { management } \\
\text { important } \\
\text { business funct. }\end{array}$ & $\begin{array}{l}\text { Environm. } \\
\text { management } \\
\text { priority item }\end{array}$ \\
\hline $\begin{array}{l}\text { Resource } \\
\text { commitment }\end{array}$ & Minimal & $\begin{array}{l}\text { Budgets for } \\
\text { problems as } \\
\text { they occur }\end{array}$ & $\begin{array}{l}\text { Consistent, } \\
\text { yet minimal }\end{array}$ & $\begin{array}{l}\text { Generally } \\
\text { sufficient }\end{array}$ & Open-ended \\
\hline $\begin{array}{l}\text { Top } \\
\text { management } \\
\text { support }\end{array}$ & $\begin{array}{l}\text { No } \\
\text { involvement }\end{array}$ & $\begin{array}{l}\text { Piecemeal } \\
\text { involvement }\end{array}$ & $\begin{array}{l}\text { Commitment } \\
\text { in theory }\end{array}$ & $\begin{array}{l}\text { Aware and } \\
\text { moderately } \\
\text { involved }\end{array}$ & $\begin{array}{l}\text { Actively } \\
\text { involved }\end{array}$ \\
\hline \multicolumn{6}{|l|}{$\begin{array}{l}\text { Programme } \\
\text { design }\end{array}$} \\
\hline $\begin{array}{l}\text { Performance } \\
\text { objectives }\end{array}$ & None & $\begin{array}{l}\text { Resolve } \\
\text { problem as } \\
\text { they occur }\end{array}$ & $\begin{array}{l}\text { Satisfy } \\
\text { corporate } \\
\text { responsibility }\end{array}$ & $\begin{array}{l}\text { Minimize } \\
\text { negative } \\
\text { env. impact }\end{array}$ & $\begin{array}{l}\text { Actively } \\
\text { manage } \\
\text { env. matters }\end{array}$ \\
\hline $\begin{array}{l}\text { Integration } \\
\text { with company }\end{array}$ & $\begin{array}{l}\text { Not } \\
\text { integrated }\end{array}$ & $\begin{array}{l}\text { Involved w. } \\
\text { other depts. } \\
\text { on piecemeal } \\
\text { basis }\end{array}$ & $\begin{array}{l}\text { Minimal } \\
\text { interaction } \\
\text { with other } \\
\text { departments }\end{array}$ & $\begin{array}{l}\text { Moderate } \\
\text { integration } \\
\text { with other } \\
\text { departments }\end{array}$ & $\begin{array}{l}\text { Actively } \\
\text { involved } \\
\text { with other } \\
\text { departments }\end{array}$ \\
\hline $\begin{array}{l}\text { Reporting to } \\
\text { top managers }\end{array}$ & None & $\begin{array}{l}\text { Exceptions } \\
\text { reporting only } \\
\text { Voluminous } \\
\text { reports that } \\
\text { are rarely read }\end{array}$ & $\begin{array}{l}\text { Consistent } \\
\text { and targeted } \\
\text { reporting }\end{array}$ & $\begin{array}{l}\text { Personal } \\
\text { meetings w. } \\
\text { managers \& } \\
\text { board }\end{array}$ & \\
\hline $\begin{array}{l}\text { Reporting } \\
\text { structures }\end{array}$ & None & $\begin{array}{l}\text { Exceptions } \\
\text { reporting only }\end{array}$ & $\begin{array}{l}\text { Internal } \\
\text { reporting only }\end{array}$ & $\begin{array}{l}\text { Mostly } \\
\text { internal } \\
\text { with some } \\
\text { external }\end{array}$ & $\begin{array}{l}\text { Formalized } \\
\text { internal and } \\
\text { external } \\
\text { reporting }\end{array}$ \\
\hline \multicolumn{6}{|l|}{ Involvement w. } \\
\hline Public rel. & None & None & Moderate & High & Daily \\
\hline $\begin{array}{l}\text { Manufact./ } \\
\text { production }\end{array}$ & None & None & None & Moderate & Daily \\
\hline Prod. design & None & None & None & Minimal & Daily \\
\hline
\end{tabular}

Adapted from Hunt and Auster (1990, p. 9).

the 'stages' which constitute the previous four strategic options.

Roome stresses the need for 'planned and programmed change in support of environmental management' ( $p$ 19) and sets out a number of characteristics that companies at the 'compliance', the 'compliance-plus' and the 'commercial and environmental excellence' stage should meet. These are shown in Table 3 of the main text of this article.

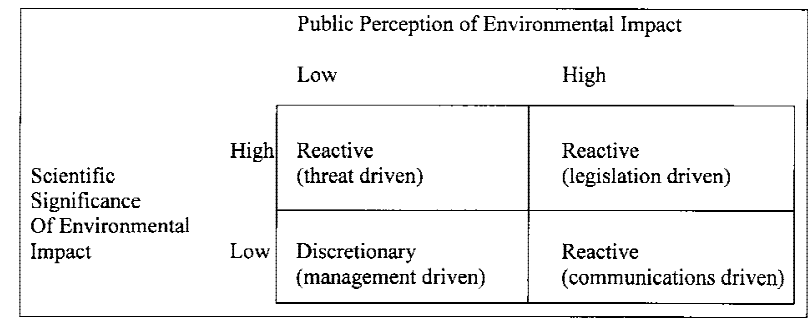

Adapted from Roome (1992), p. 17

Figure A1. Corporate vulnerability to environmental pressure according to Roome (1992). 


\section{ACKNOWLEDGEMENT}

The research on which this article is based was funded by the Economic and Social Research Council under the Global Environmental Change Programme, Phase 4, Grant No. L 321253209.

\section{REFERENCES}

Ansoff, H.I. (1965) Corporate Strategy, McGraw-Hill, New York.

Ansoff, H.I. (1979) Strategic Management, Macmillan, London.

Chandler, A.D., Jr. (1962) Strategy and Structure: Chapter in the History of the Industrial Enterprise, MIT Press, Cambridge, MA.

Chandler, A.D., Jr. (1977) The Invisible Hand, Harvard University Press, Cambridge, MA.

Elkington, J. (1994) Towards the sustainable corporation: win - win - win business strategies for sustainable development, California Management Review, Winter, 90-100.

Freeman, J. and Hannan, M.T. (1983) Niche width and the dynamics of organizational populations, American Journal of Sociology, 6, 1116-1145.

Garrod, B. and Chadwick, P. (1996) Environmental management and business strategy: towards a new strategic paradigm, Futures, 28, 37-50.

Gersick, C.J.G. (1991) Revolutionary change theories: a multilevel exploration of the punctuated equilibrium paradigm, Academy of Management Review, 16, 10-36.

Greeno, J.L. (1991) Environmental excellence: meeting the challenge, Arthur D Little: Prism, third quarter, 13-31.

Hass, J.L. (1996) Environmental ('green') management typologies: an evaluation, operationalization and empirical development, Business Strategy and the Environment, 5, 59-68.

Hedlund, G. (1994) A model of knowledge management and the N-Form Corporation, Strategic Management Journal, 15, 73-90.

Huber, G.P. (1991) Organizational learning: the contributing processes and the literatures, Organization Science, 2, 88-115.

Hunt, C.B. and Auster, E.R. (1990) Proactive environmental management: avoiding the toxic trap, Sloan Management Review, 31, 7-18.

Kleiner, A. (1991) What does it mean to be green?, Harvard Business Review, July/August, 38-47.

Mintzberg, H. (1994), The Rise and Fall of Strategic Planning, Prentice-Hall, New York.

Morgan, G. (1982) Cybernetics and organization theory: epistemology or technique?, Human Relations, 35, 521-537.

Morgan, G. (1989) Creative Organization Theory: a Resourcebook, Sage, Newbury Park, CA.

Morgan, G. (1997) Images of Organization, 2nd edn, Sage, Thousand Oaks, CA.

Newman, J.C. (1993) Opportunity knocks, and leaders answer, Directors $\mathcal{E}$ Boards, Fall, 32-48.

Nicolini, D. and Meznar, M.B. (1995) The social construction of organizational learning: conceptual and practical issues in the field, Human Relations, 48, 727-746.
Nonaka, I. (1994) A dynamic theory of organizational knowledge creation, Organization Science, 5, 14-37.

North, D.C. (1990) Institutions, Institutional Change and Economic Performance, Cambridge University Press, Cambridge.

Pettigrew, A.M. (1988) Introduction: researching strategic change, in: Pettigrew, A.M. (ed.), The Management of Strategic Change, Blackwell, Oxford.

Pettigrew, A.M. and Whipp, R. (1991) Managing Change for Competitive Success, Blackwell, Oxford.

Powell, W. and DiMaggio, P.J. (eds) (1990) The New Institutionalism in Organizational Analysis, Chicago, IL: University of Chicago Press.

Räsänen, K., Meriläinen, S. and Lovio, R. (1995) Pioneering descriptions of corporate greening: notes and doubts on the emerging discussion, Business Strategy and the Environment, 3, 9-16.

Roome, N. (1992) Developing environmental management strategies, Business Strategy and the Environment, 1, 11-24.

Schmidheiny, S. (1992) Changing Course: a Global Business Perspective on Development and the Environment, MIT Press, Cambridge, MA.

Shrivastava, P. (1995) Creating sustainable corporations, Business Strategy and the Environment, 4, 154-165.

Stead, W.E. and Stead, J.G. (1996) Management for a Small Planet, 2nd edn, Sage, Thousand Oaks, CA.

Tushman, M.L. and Romanelli, E. (1985) Organizational evolution: a metamorphosis model of convergence and reorientation, in: Staw, B.M. and Cummings, L.L. (eds), Research in Organizational Behavior, JAI, Greenwich, CT, Vol. 7, pp 171-222.

Walley, N. and Whitehead, B. (1994) It's not easy being green, Harvard Business Review, May - June, 46-52.

Whittington, R. (1993) What is Strategy - and Does it Matter?, Routledge, London.

Wilson, D.C. (1992) A Strategy of Change: Concepts and Controversies in the Management of Change, Routledge, London.

Winsemius, P. and Guntram, U. (1992) Responding to the environmental challenge, Business Horizons, March/April, 12-20.

\section{BIOGRAPHY}

Dr Anja Schaefer is Lecturer in Management at King's College London. Previously she worked as a Research Associate in Business Strategy and Management at the Manchester Business School. She holds a DPhil from the University of Buckingham, UK. Her research interests include consumer behaviour, environmental strategy and management and organizational change.

Professor Brian Harvey is Professor of Corporate Responsibility at the Manchester Business School. He holds a PhD from the University of Nottingham, UK. His research interests include business ethics, corporate governance, and environmental strategy and management. 
Address for correspondence: Anja Schaefer, King's College London, The Management Centre, Kensington Campus, Campden Hill Road, London
W8 7AH, UK. Tel/Fax: 0171333 4211. E-mail: anja.schaefer@kcl.ac.uk 
Copyright of Business Strategy \& the Environment (Wiley) is the property of John Wiley \& Sons, Inc. / Business and its content may not be copied or emailed to multiple sites or posted to a listserv without the copyright holder's express written permission. However, users may print, download, or email articles for individual use. 